Hum. Genet. 37, 207-219 (1977)

\title{
Genetic Studies of the Macushi and Wapishana Indians
}

\author{
II. Data on 12 Genetic Polymorphisms of the Red Cell \\ and Serum Proteins: \\ Gene Flow between the Tribes
}

\author{
James V. Neel ${ }^{1}$, Henry Gershowitz ${ }^{1}$, Richard S. Spielman ${ }^{1 *}$, \\ Ernest C. Migliazza ${ }^{* *}$, Francisco M. Salzano ${ }^{2}$, and William J. Oliver ${ }^{3}$ \\ ${ }^{1}$ Department of Human Genetics, University of Michigan Medical School, \\ Ann Arbor, Michigan 48109, USA \\ ${ }^{2}$ Departamento de Genetica, Universidade de Rio Grande do Sul, Caixa Postal 1953, \\ Porto Alegre, R.G.S., Brasil \\ ${ }^{3}$ Department of Pediatrics, University of Michigan School of Medicine, \\ Ann Arbor, Michigan 48 109, USA
}

Summary. Blood samples from 509 Macushi (3 villages) and 623 Wapishana (11 villages) of Northern Brasil and Southern Guyana have been analyzed with respect to the phenotype and gene frequencies at the following 12 polymorphic loci: AB0, Kell-Cellano, MNSs, Rh, P, Duffy, Kidd, Diego, Lewis, Group-specific component, and the immunoglobulin allotypes of the $\mathrm{Gm}$ and Inv systems. The data suggest that $5-6 \%$ of the Wapishana gene pool is derived from non-Indians but only $1-2 \%$ of the Macushi. Inter- and intratribal genetic distances between villages are calculated for these data in an effort to understand gene flow between the tribes and to account for the unusual distribution of a newly-discovered genetic polymorphism of erythrocyte esterase A thus far limited to these 2 tribes (Neel et al., 1977). The data are puzzling and consistent with the possibility that both the Carib-speaking Macushi and the Arawak-speaking Wapishana have derived the esterase A allele in question from some third group now extinct or thus far undiscovered. Intertribal genetic distances based on gene frequencies at 6 loci are derived for 20 Amerindian tribes (including these 2); the "central" position of these 2 tribes can in part be explained by the active migration matrix connecting them.

In the previous paper in this series (Neel et al., 1977), we have described the findings with respect to rare variants of 25 proteins of the blood serum and erythrocyte in a sample of 509 Macushi and 623 Wapishana Amerindians. The

\footnotetext{
* Present address: Department of Human Genetics, University of Pennsylvania School of Medicine, Philadelphia, Pennsylvania 19 174, USA

** Present address: Department of Anthropology, University of Maryland, College Park, Maryland, 20 742, USA
} 
salient finding was the occurrence of a previously undescribed allele of Esterase A $\left(E S A_{1}^{\mathrm{D}}\right)$ in polymorphic proportions in both tribes. In this paper we report the results of typings for 12 additional systems characterized by genetic polymorphisms. The primary use of the findings at this time will be an attempt to analyze the genetic distances and the pattern of gene flow between the villages of these 2 tribes (and from the 'outside world'), in order to understand the distribution of the Esterase $\mathrm{A}$ and other variants. We will also consider how these new data alter the apparent positions of these tribes in a matrix of genetic distances based on 20 Amerindian tribes. In subsequent papers the data will be employed for an analysis of gametic disequilibrium and for an analysis of the genetic relationships of the Amerindian tribes of Central and South America.

\section{Material and Methods}

The Macushi and Wapishana are 2 semi-acculturated Amerindian tribes located in the Roraima Territory of Northern Brazil and in Southern Guyana. A brief history of the tribes and the locations of the 3 Macushi and 11 Wapishana villages sampled will be found in the previous paper in the series (Neel et al., 1977).

Typings were performed with respect to the following systems: AB0, Kell-Cellano (K-k), MNSs, Rh (C, c, D, E, e), P, Duffy (Fy), Kidd (Jk), Diego (Di), Lewis (Le), Group-specificcomponent $(\mathrm{Gc})$, and the immunoglobulin allotypes of the $\mathrm{Gm}$ and Inv systems. The typing procedures employed in this laboratory have been previously characterized (Gershowitz et al., 1972). Specimens were collected in 1972 and 1974 in Becton-Dickinson vacutainers either containing no anticoagulant or ACD solution, and kept chilled following collection until they could be shipped on ice by air to Ann Arbor. The usual time from collection until receipt in the laboratory was $5-7$ days. Sera and erythrocytes were stored at $-80^{\circ} \mathrm{C}$ or in liquid nitrogen until typing. The findings in the 3 villages sampled in $1972(26 \mathrm{AB}, 26 \mathrm{CD}, 27 \mathrm{~A})$ have already been presented in part (Ward et al., 1975), but will be reproduced here in the interests of a comprehensive treatment.

\section{Results}

The findings with respect to phenotypes and gene frequencies are presented in Tables 1 and 2 .

\section{Discussion}

Comparability with Earlier Findings. Considered system by system, the present findings exhibit the village heterogeneity so characteristically observed in studies of Amerindian tribes, illustrating once again the need of a widely distributed sample in any effort to estimate tribal gene frequencies. As noted earlier (Neel et al., 1977), the sample of Macushi analyzed by Layrisse et al. (1963) was drawn from the vicinity of Lethem, Guyana. Our results for $M N S s, P$, and $J^{\text {a }}$ differ substantially from theirs but there is satisfactory agreement as regards $R h, F y^{\text {a }}$ and $D i{ }^{\text {a }}$; we attribute the differences to the tribal heterogeneity mentioned above. Two of the three areas in which Matson et al. (1968) drew their samples of 


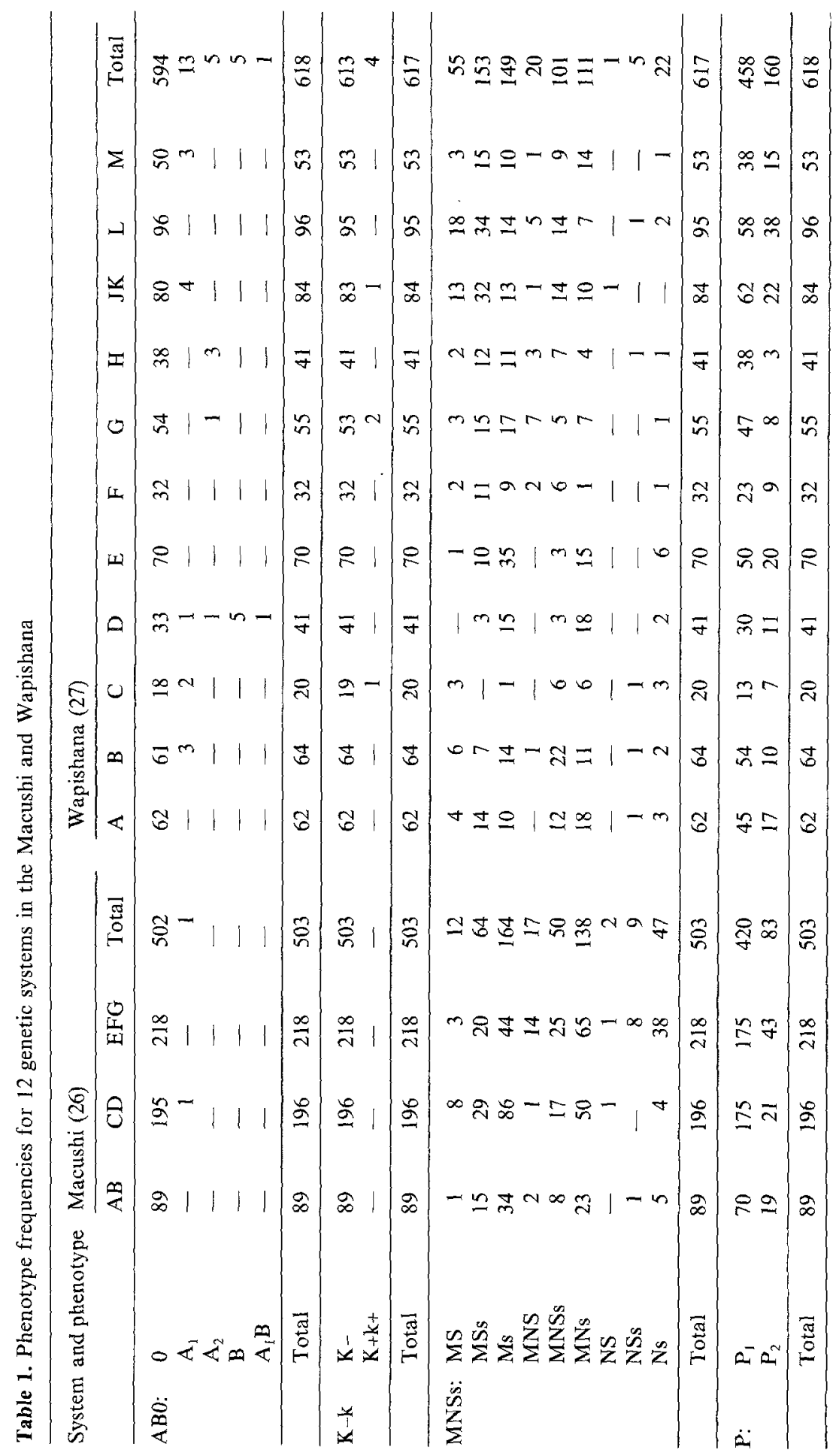




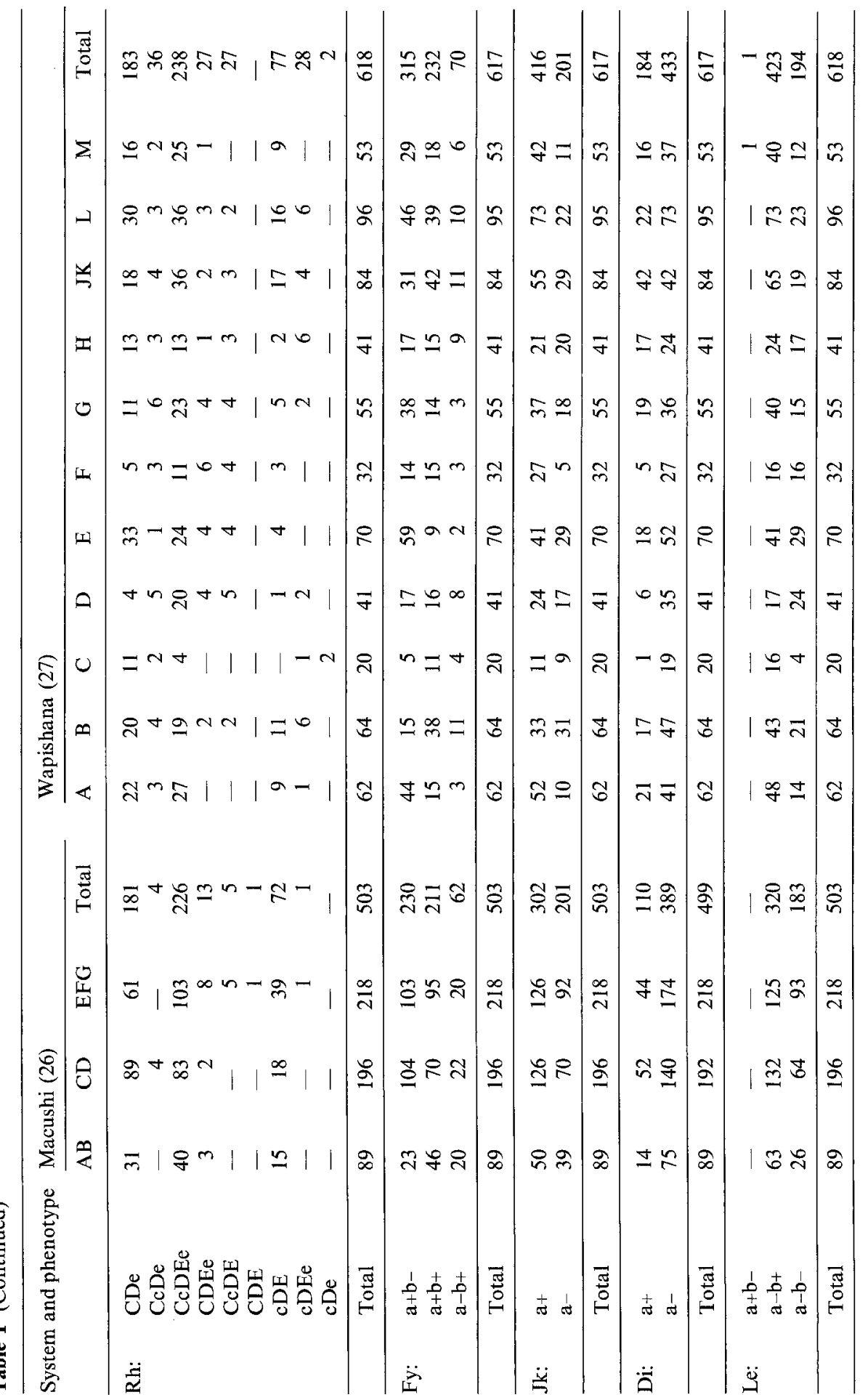




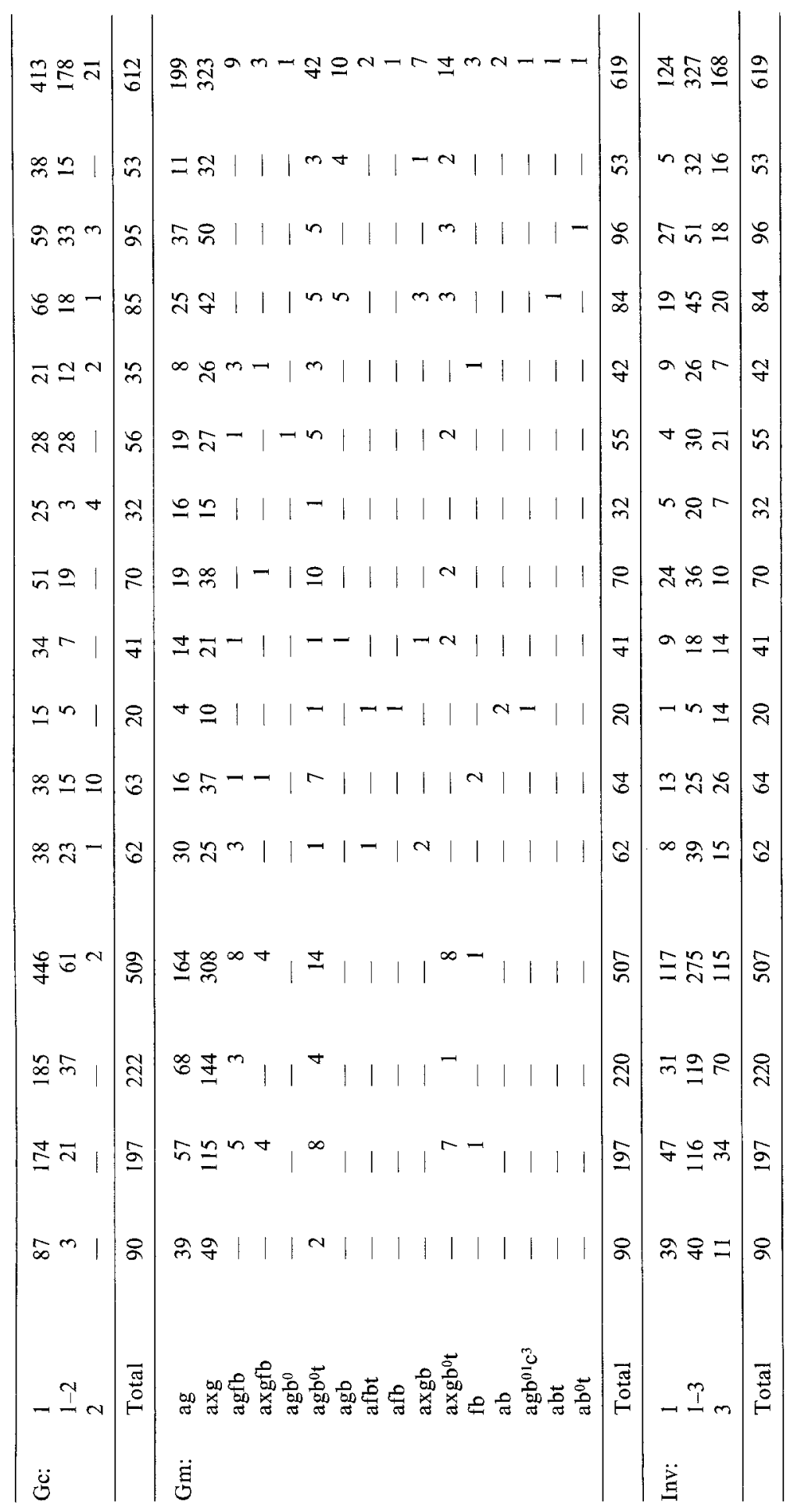




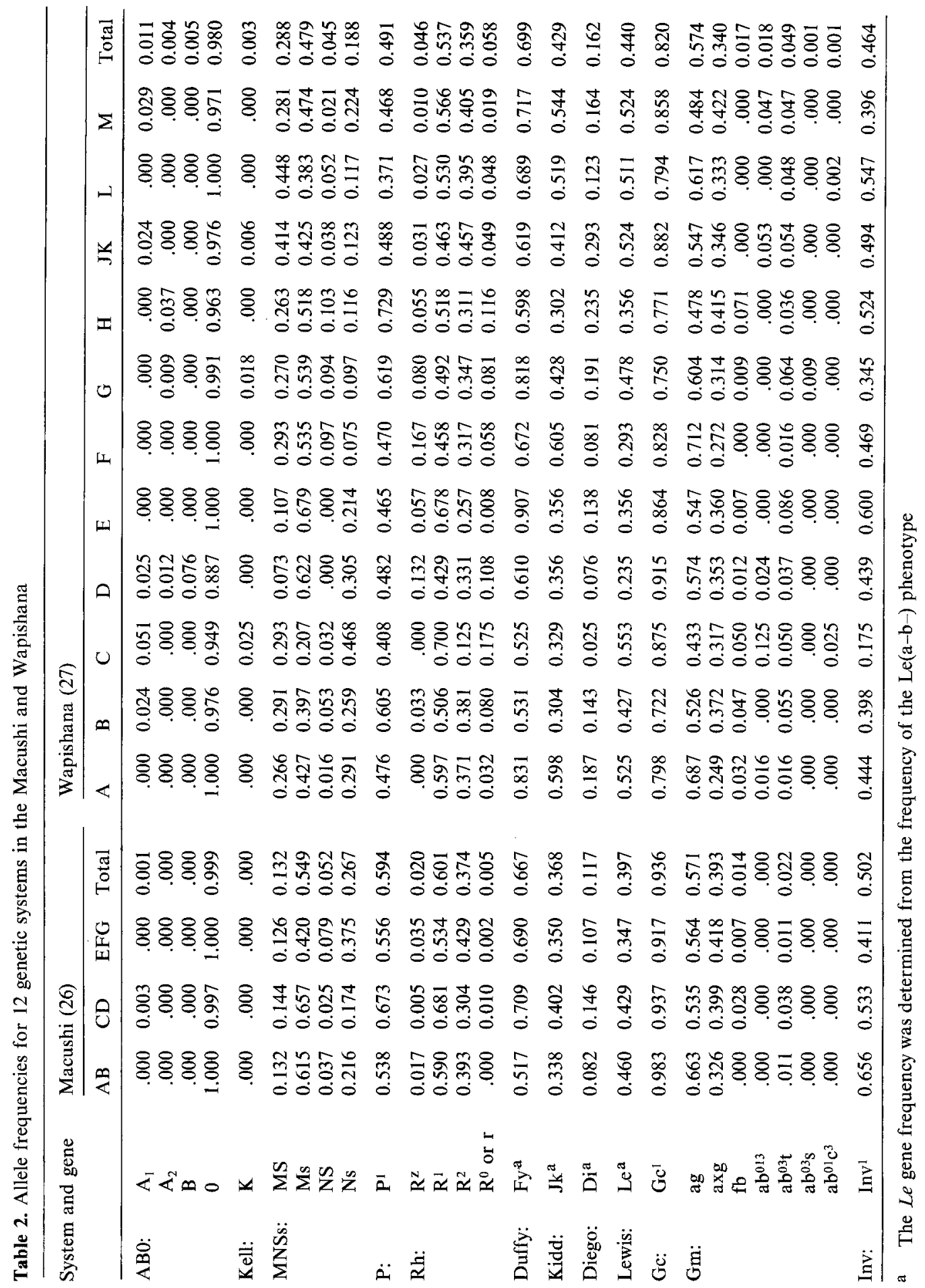


Macushi involve villages included in our samplings (26CD and 26DEF; Contão and Raposa, respectively). Given the lapse of time, the difference in sample size, and the fact that the collection points do not completely overlap, there is agreement between their earlier results and the present findings with respect to the Rh, MNSs, P, Fy, Di, Le and the Jk systems. We also find, in agreement with the earlier work, a very low frequency of non-0 types in the $\mathrm{AB} 0$ system and the absence of the $K$ antigen of the Kell-Cellano system. With respect to the Wapishana, there are again considerable differences between some of our results $\left(S\right.$ of MNSs, $J k^{\text {a }}$ ) and those of Layrisse and Wilbert (1966) involving a sample of Wapishana from Lethem, Guyana which, as before, we attribute to tribal heterogeneity; we find more evidence for admixture with non-Indians than they did.

Evidence of Admixture with Neo-Brazilians. Three systems are especially suitable in providing evidence for the admixture of these 2 tribes with non-Indians: AB0, Kell and Gm. From the first, we can get an estimate of combined NegroCaucasian admixture; from the second, of Caucasian; and from the third, separate estimates of Negro and of Caucasian admixture. For all 3 systems, the unmixed Indian populations of South America lack alleles present in Negro and/or Caucasian populations.

As noted above, the preliminary results of others had shown no evidence of non-Indian admixture involving these 2 tribes except for 2 non-0 Macushi encountered by Matson et al. (1968), but the present data indicate otherwise. We consider the Wapishana first. Using an estimate of a combined frequency of non0 alleles in the AB0 system of 0.35 in the Negroes and Caucasians who entered northern South America, the usual formula for admixture (Boyd, 1950), given the present findings, yields an estimate of $5.7 \%$ for Negro and Caucasian admixture combined. The Kell system, assuming Caucasians to be the sole source of the $K$ allele, with the frequency of 0.05 , yields an estimate, for the Caucasoid contribution, of $6.0 \%$. Finally, assuming a frequency of 0.995 for the combined Negro Gm haplotypes detectable in Indian populations (chiefly, $a b^{013}, a b^{03} \mathrm{~s}$, $a b^{01} \mathrm{c}^{35}$ ), the data suggest a Negro contribution of $2.1 \%$, and assuming the $\mathrm{Gm}(\mathrm{fb})$ specificities to have been derived solely from Caucasians, where the responsible haplotype has a frequency of 0.69 , the Caucasian contribution is estimated to be $2.5 \%$. Because of the extensive relationships among the members of this sample, the errors to be attached to these estimates cannot be readily calculated but must be considerable. We will settle for an estimate of admixture with non-Indians of 5 or $6 \%$, with the Caucasoid contribution somewhat greater than the Negro. By these same approaches, the contribution of Caucasians to the present Macushi gene pool can be placed at about $1-2 \%$; the Gm system provides no evidence of Negro admixture in the Macushi.

These figures suggest that roughly 5 and $1 \%$ of the variants described earlier in the Wapishana and Macushi, respectively, have been introduced into these tribes, but that if any effort is to be made to correct for this possibility, there must be a corresponding adjustment with respect to the number of Indian loci sampled. Among the Wapishana, exclusive of the ESA 1 variant, 72 variants were observed in 15396 determinations. Elimination of the variants of ADA and $\mathrm{CA}_{\mathrm{II}}$ from 
consideration, on the grounds that the case for their introduction by non-Indians is rather compelling, reduces the number of variants to 67 . A 5\% reduction in the number of determinations, to adjust for the non-Indian component of the Wapishana, yields a figure of 14626 . The adjusted variant frequency becomes $4.6 / 1000$, in contrast to the unadjusted figure of $4.7 / 1000$. With respect to the Macushi, we have earlier questioned whether a C-type variant of $\mathrm{ACP}_{1}$ encountered in a single person may have been introduced. Elimination of this variant, with a corresponding $1 \%$ adjustment in the number of examinations, leaves the variant frequency, of 1.1/1000 determinations, unchanged. Clearly these "adjustments" cannot be rigorously defended, since any or all of these variants could conceivably be of Indian origin, but in the present effort to develop a comprehensive picture of rare variants in Amerindians, this seems the conservative course.

An Intervillage Genetic Distance Matrix for the Macushi and Wapishana and Its Relevance to the Origin of the ESA $A_{1}^{\mathrm{D}}$ Polymorphism. Table 3 presents 2 matrices of genetic distances within and between the villages of the Macushi and Wapishana, the lower triangular matrix based on the allele frequencies of only 6 loci ( $R h, M N S s, F y, J k, D i, H p$ ) (to be comparable with earlier publications), the upper based on the maximum number of loci possible from these data (those 6 plus P, Lewis, Gc, Gm, Inv, $P G M_{1}, A C P_{1}$ and $E S D$ ). Distances have been computed by the stereographic projection of Edwards (1971). There are a number of salient points:

a. The mean, 6-locus intervillage distance for the Macushi is 0.209 and for the Wapishana, 0.347. The corresponding figure for 7 Makiritare villages was 0.356 and for 7 Yanomama villages, 0.330 (Neel and Ward, 1970). These tribes are of different linguistic stocks (Makiritare, Carib; Yanomama, unclassified). For 3 Xavante, 5 Cayapo and 2 Kraho villages (all 3 tribes Gé-speakers) the corresponding intratribal, intervillage distances were 0.199, 0.223 and 0.208 (Salzano et al., 1977). These smaller distances than for the Makiritare and Yanomama were attributed to the larger size and greater temporal stability of the villages of these Gé-speaking tribes. The 3 Macushi villages thus show about the same amount of microdifferentiation as those of the Gé tribes, but the Wapishana villages despite their acculturation and resulting village stability differ genetically from one another as much as the villages of the unacculturated Yanomama and Makiritare. The history of Wapishana admixture with other tribes is complex (cf. Neel et al., in press). It is a reasonable working hypothesis that both this admixture and that with Caucasians and Negroes has been non-uniform by village, this resulting in the relatively large intervillage genetic distances.

b. Both the 6- and the 14-locus intervillage distances can supply a type of evidence relative to the origin and flow of the $E S A_{1}^{\mathrm{D}}$ allele. We note from Table 3 that the mean of the 33 intertribal village distances is 0.335 for the 6-locus matrix and 0.518 for the 14-locus matrix. Now, the villages in which the $E S A_{1}^{\mathrm{D}}$ allele occur are 26AB, 26EFG (Macushi) and 27A, 27C, 27L and 27M (Wapishana), although among the latter 4 villages, the trait is substantially represented only in 27A. The mean of the 8 intertribal village distances defined by these 6 villages is 0.349 (6-locus) or 0.506 (14-locus). The corresponding figure for the 25 remaining 


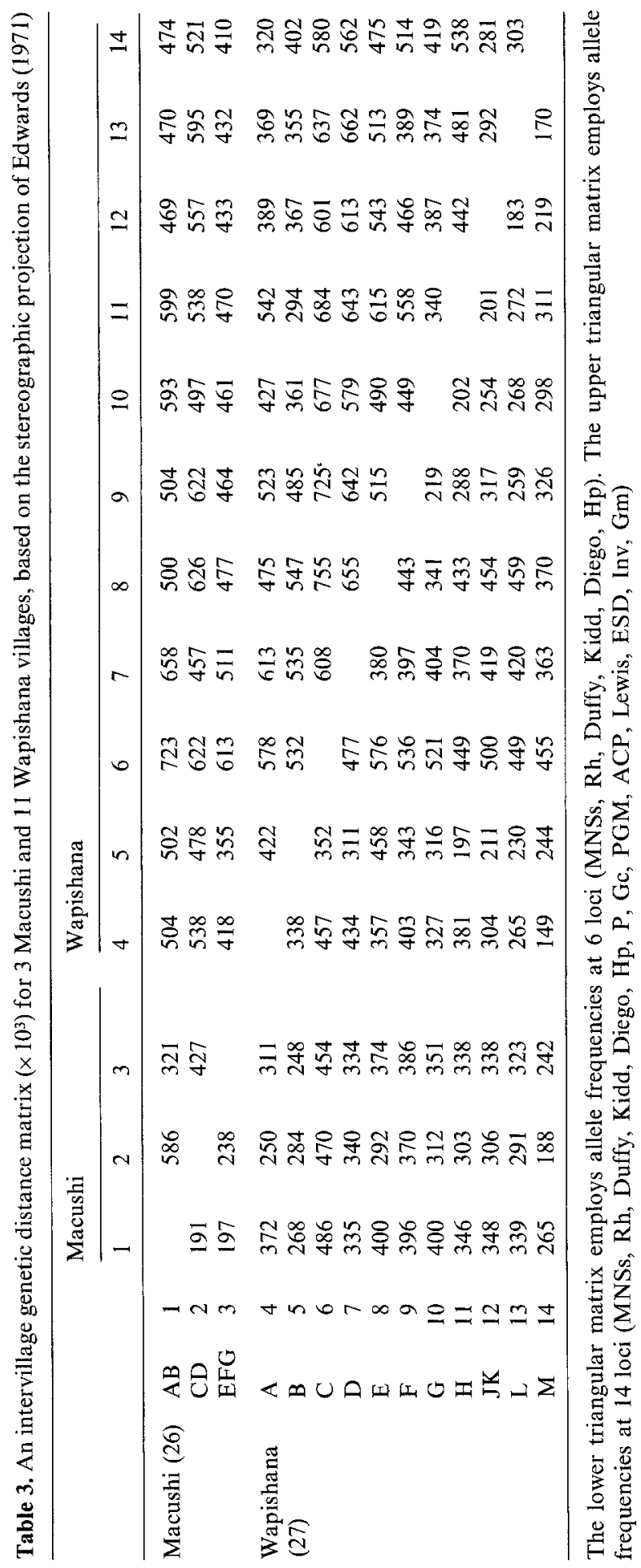


contrasts is 0.331 (6-locus) or 0.522 (14-locus). Thus in an across-tribe contrast the villages in which the $E S A_{1}^{\mathrm{D}}$ allele occurs are no more alike one another genetically than the villages in which $E S A_{1}^{\mathrm{D}}$ does not occur.

In the preceding paper, we pointed out that the frequency of the $E S A_{1}$ allele was relatively low both in Macushi and their (mixed) descendants living among Wapishana and in Wapishana and their (mixed) descendants living among Macushi. Although the spotty distribution of the gene renders generalization hazardous, this finding seemed more consistent with the origin of the gene from a third (unknown) source than from either tribe. We now have the additional evidence that the villages in which this gene is found do not exhibit any marked genetic resemblance; this fact is neither consonant with a flow from one tribe to another nor with flow from a third source.

c. There is one more potential piece of evidence regarding the nature of the gene flow between the 2 tribes. Layrisse and Wilbert (1966) in discussing the degree of admixture of the Wapishana with neighboring tribes, especially the Macushi, noted a $D i{ }^{a}$ frequency of 0.150 in a sample of 119 Wapishana, whereas the other Arawak speakers they had studied usually had lower allele frequencies, and wrote ". . . although an intertribal admixture of up to $50 \%$ (with Carib Indians) is difficult to assume under other circumstances, we believe that the evidence cited here justifies the assumption in the case of the Wapishana and Guiana Indian tribes". The present studies reveal a mean $D i$ a frequency of 0.162 among the Wapishana, but village frequencies ranging from 0.025 to 0.293 . Our larger data set thus tends to confirm the findings of Layrisse and Wilbert (1966). However, we note from Table 2 that $D i$ a has a higher frequency in the Wapishana than in the Carib tribe, the Macushi, with which admixture is best documented. In this particular instance we thus have no evidence from this (or any other) genetic system of the magnitude of incorporation of Macushi into Wapishana (against which to contrast the $E S A_{1}^{\mathrm{D}}$ allele frequencies). Indeed, the high $D i^{\mathrm{a}}$ frequency of the Wapishana can be viewed as evidence for major gene flow from a tribe other than the Macushi, a tribe which could also have been the source of the $E S A_{1}^{\mathrm{D}}$ allele.

The obvious next step in unraveling this mystery is a study of the $E S A_{1}^{\mathrm{D}}$ frequency among the Northern Macushi. If the allele were lacking or in very low frequency there, the case for the origin of the gene external to both tribes would be strengthened. In addition, of course, a sampling of the tribes adjacent to the Macushi and Wapishana should be expected to illuminate the situation.

A. Revised Distance Matrix for 20 Amerindian Tribes. Earlier, when we had studied only one village of the Wapishana and of the Macushi, we published a 20tribe genetic distance matrix, based on the $\mathrm{Rh}, \mathrm{MNSs}, \mathrm{Fy}, \mathrm{Jk}$, Di and $\mathrm{Hp}$ systems, in which these 2 tribes were represented by those single villages (Ward et al., 1975). Table 4 is a revised matrix incorporating the additional data of this paper. There has been no substantial change in the position of the Macushi with the addition of two villages to the original one, as measured by mean genetic distance to the other 19 villages (old matrix, 0.348 units; new matrix, 0.296 units). However, not unexpectedly, with the addition of 10 villages to the original one, the position of the Wapishana in the matrix has altered more markedly, again as 


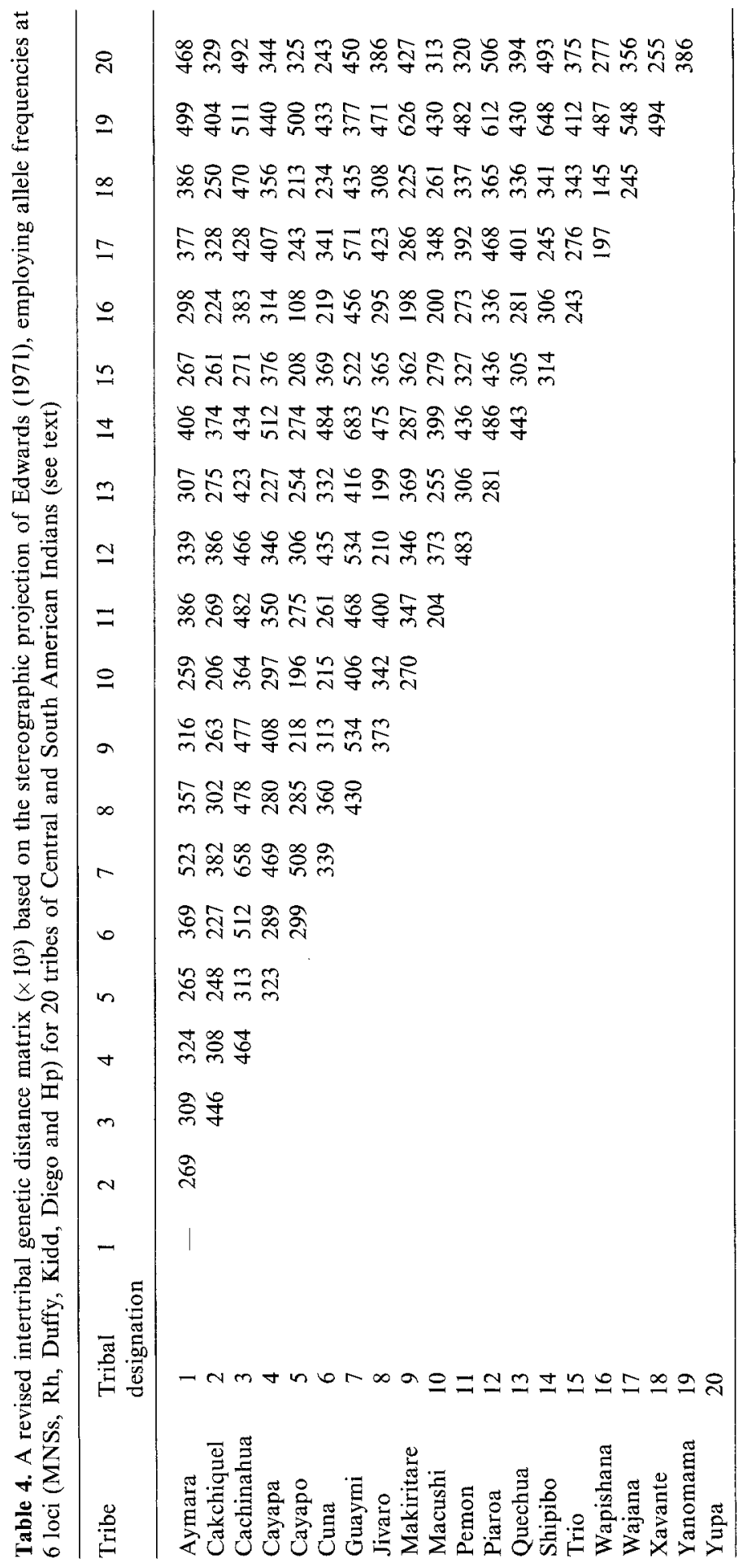


measured by mean genetic distance to the other 19 villages (old matrix, 0.391 units; new matrix, 0.276 units). Here is a striking demonstration of the need for adequate tribal samples in any effort to demonstrate the relationships of the Amerindian tribes to one another.

In the revised matrix of Table 4, the Wapishana now emerge as exhibiting a smaller mean distance from all the other 19 tribes than any other tribe. This is tantamount to the statement that they most nearly approximate the "average" Indian. The Macushi also show a relatively small average distance. In this matrix prior to the current revision, the Xavante and Cayapo exhibited the smallest mean differences from the other tribes, and on this basis plus their consequent central position in the isocline representation of Amerindian relationships in Ward et al. (1975), we suggested that the gene frequencies of the Xavante and Cayapo "are more representative of at least one of the stocks which originally entered South America than the frequencies of any other defined group of Indians" (Salzano et al., in press). The central position of these two groups is now contested by the Wapishana and Macushi (Cayapo av. distance, 0.282; Xavante, 0.316). However, we may speculate that whereas the central genetic position of the 2 Gé-speaking tribes is indeed attained through minimal differentiation from one of the founding stocks, that of the Wapishana and Macushi results from admixture which has tended to recreate the gene frequencies of the same stock. The latter 2 tribes would represent the type of fusion event which necessitates caution in equating a dendrogram to a phylogeny.

A subject of perennial interest to anthropologists and geneticists is the degree of correlation of genetic distance with linguistic distance. With respect only to Amerindians, Spuhler (1972), reviewing the available data on Indian tribes of North and Central America, found that intertribal genetic distance was less within linguistic families than across linguistic families but that for the total material there was a negative correlation of -0.33 between the entries in a genetic distance matrix and the entries in a matrix of elapsed time since tribal separation as judged by glottochronology, a finding contrary to hypothesis. On the other hand, Spielman et al. (1974) in an analysis of intratribal linguistic and genetic differentiation among 7 Yanomama subpopulations, for whom both more genetic and linguistic data were available than in Spuhler's analysis, found a correlation between corresponding entries in matrices of percent cognates (on which glottochronology is based) and genetic distances of -0.36 (now and in the rest of this discussion, a negative sign is consistent with hypothesis). When the analysis was extended to a comparison of cluster structure within the matrices by several techniques, correspondences at the 0.01 probability level were observed. More recently, Salzano et al. (in press) have shown that the genetic distances between 3 Gé-speaking tribes of South America average $64 \%$ as great as those between some 20 tribes of Central and South America. For only 6 South American tribes were data available on the 6-locus allele frequencies used in the derivation of our distances and the Swadesh list of 100 lexical items; the intertribal correlation between the corresponding entries in the genetic and cognate matrices was -0.27 . Error terms cannot be attached to these correlations for several reasons. The present data clearly demonstrate the need for extreme caution in this type of analysis. The Wapishana by virtue of their admixture are completely unsuitable for inclusion in a 
study of the correlation between genetic and linguistic distance. Unfortunately, for many tribes data on their admixture with other tribes are either unavailable or have been overlooked.

Research supported by the National Science Foundation and the Energy Research and Development Administration.

\section{References}

Boyd, W. C.: Genetics and the races of man. Boston: Little, Brown 1950

Edwards, A. W. F.: Distances between populations on the basis of gene frequencies. Biometrics $27,873-881(1971)$

Gershowitz, H., Layrisse, M., Layrisse, Z., Neel, J. V., Chagnon, N., Ayres, M.: The genetic structure of a tribal population, the Yanomama Indians. II. Eleven blood-group systems and the ABH-Le secretor traits. Ann. Hum. Genet. 35, 261-269 (1972)

Layrisse, M., Layrisse, Z., Wilbert, J.: The blood groups of northern continental Caribs. Hum. Biol. 35, 140-166 (1963)

Layrisse, M., Wilbert, J.: Indian societies of Venezuela. Monograph no. 13. Caracas: Fundación la Salle de Ciencias Naturales 1966

Matson, G. A., Sutton, H. E., Pessoa, E. M., Swanson, J., Robinson, A.: Distribution of hereditary blood groups among Indians in South America. V. In Northern Brazil. Amer. J. Phys. Anthrop. 28, 303--330 (1968)

Neel, J. V., Tanis, R. J., Migliazza, E. C., Spielman, R. S., Salzano, F., Oliver, W. J., Morrow, M., Bachofer, S.: Genetic studies of the Macushi and Wapishana Indians. I. Rare genetic variants and a "private polymorphism" of Esterase A. Hum. Genet. 36, 81-107 (1977)

Neel, J. V., Ward, R. H.: Village and tribal genetic distances among American Indians, and the possible implications for human evolution. Proc. Nat. Acad. Sci. (Wash.) 65, 323-330 (1970)

Salzano, F. M., Neel, J. V., Gershowitz, H., Migliazza, E. C.: Intra- and intertribal genetic variation within a linguistic group: The Gé-speaking Indians of Brazil. Amer. J. Phys. Anthrop. (in press)

Spielman, R. S., Miggliazza, E. C., Neel, J. V.: Regional linguistic and genetic differences among Yanomama Indians. Science 184, 637-644 (1974)

Spuhler, J. N.: Genetic, linguistic and geographical distances in native North America. In: The assessment of population affinities in man, J. S. Weiner and J. Huizinga, eds., pp. 72-95. Oxford: Clarendon Press 1972

Ward, R. H., Gershowitz, H., Layrisse, M., Neel, J. V.: The genetic structure of a tribal population, the Yanomama Indians. XI. Gene frequencies for 10 blood groups and the $\mathrm{ABH}-\mathrm{Le}$ secretor traits in the Yanomama and their neighbors; the uniqueness of the tribe. Amer. J. Hum. Genet. 27, 1-30 (1975) 